\title{
Differences in Social Determinants of Health between Urban Indigenous Migrants and Non-Indigenous People in North-Eastern Mexico: An Analysis to Prioritize
}

\author{
Georgina Mayela Núñez-Rocha ${ }^{1, * \mathbb{D}}$, Brenda Mayela Esqueda-Eguía ${ }^{1} \mathbb{C}$, Ana María Salinas-Martínez ${ }^{1,2} \mathbb{D}_{\text {, }}$ \\ María Natividad Ávila-Ortiz ${ }^{1}{ }^{D}$, Ana Elisa Castro-Sánchez ${ }^{1} \mathbb{D}$, Adriana Zambrano-Moreno ${ }^{1}$ (D) \\ and Karina Janett Hernández-Ruiz ${ }^{1}$ (D) \\ 1 Facultad de Salud Pública y Nutrición, Universidad Autónoma de Nuevo León, Nuevo León 66455, Mexico; \\ brenda.esquedaeg@uanl.edu.mx (B.M.E.-E.); amsalinasmartinez@gmail.com (A.M.S.-M.); \\ natividad.avilao@uanl.mx (M.N.Á.-O.); ana.castrosh@uanl.edu.mx (A.E.C.-S.); \\ adriana.zambranom@uanl.mx (A.Z.-M.); karina.hernandezr@uanl.mx (K.J.H.-R.) \\ 2 Unidad de Investigación Epidemiológica y en Servicios de Salud, Instituto Mexicano del Seguro Social, \\ Nuevo León 64360, Mexico \\ * Correspondence: georgina.nunezr@uanl.mx
}

Citation: Núñez-Rocha, G.M.;

Esqueda-Eguía, B.M.;

Salinas-Martínez, A.M.; Ávila-Ortiz, M.N.; Castro-Sánchez, A.E.; Zambrano-Moreno, A.

Hernández-Ruiz, K.J. Differences in Social Determinants of Health between Urban Indigenous Migrants and Non-Indigenous People in North-Eastern Mexico: An Analysis to Prioritize. Int. J. Environ. Res. Public Health 2021, 18, 8464. https:// doi.org/10.3390/ijerph18168464

Academic Editor: Kevin Pottie

Received: 7 June 2021

Accepted: 6 August 2021

Published: 11 August 2021

Publisher's Note: MDPI stays neutral with regard to jurisdictional claims in published maps and institutional affiliations.

Copyright: (c) 2021 by the authors. Licensee MDPI, Basel, Switzerland. This article is an open access article distributed under the terms and conditions of the Creative Commons Attribution (CC BY) license (https:// creativecommons.org/licenses/by/ $4.0 /)$.

\begin{abstract}
The degree to which social determinants of health differ between indigenous migrants and non-indigenous people born and raised locally is currently unknown. We compared social determinants of health between indigenous migrants and non-indigenous people from urban northeastern Mexico. Additionally, we ranked priorities for addressing the negative social determinants of health. This was a population-based comparative cross-sectional study ( $n=235$ indigenous migrants and 168 non-indigenous people). A two-stage non-random sampling was carried out from June to August of 2019. Heads of households $\geq 18$ years and those with the ability to communicate in Spanish were recruited house by house. Structural and intermediary determinants of health were identified according to the World Health Organization Conceptual Framework and priorities were ranked using Z-scores. Being a migrant indigenous increased 1.6 times the odds of low education $(95 \% \mathrm{CI}=1.1,2.4)$. In addition, the migrant indigenous status increased the odds of poor housing, unhealthy behaviour and low social cohesion $(p<0.05)$. Housing, behaviours and health service accessibility were top priorities for indigenous migrants and structural determinants for non-indigenous people. The findings show that the right to access the social determinants of health has not yet been guaranteed for indigenous communities.
\end{abstract}

Keywords: social determinants of health; indigenous population; migration; vulnerable groups

\section{Introduction}

The World Health Organization has called attention to social inequalities and the social determinants of health [1,2]. The social determinants of health are non-medical factors (education, income, job and food security, housing, non-discrimination and access to health services, among other) that influence health outcomes [3]. Social determinants of health may vary by indigenous status. Studies reveal that negative social determinants are greater in indigenous populations than in non-indigenous communities, even in countries with high human development $[4,5]$. A lack of social determinants of health creates undesirable circumstances such as disparities, discrimination and social injustice, all of which lead to poor health consequences over multiple generations. There are over 370 million indigenous peoples living in approximately 90 countries with low standards of health [6]. In Mexico, there are 68 indigenous groups and more than 25 million people who self-describe themselves as indigenous, a figure that represents $21.5 \%$ of the country's total population. A high percentage do not have proper housing and have less access to education and formal jobs. Their health needs are high and their access to health care is 
poor, forcing them to migrate [7-9]. This country has documented $57.5 \%$ of indigenous people with poor access to basic housing and $31.5 \%$ with poor access to food compared to $15.5 \%$ and $29.2 \%$ of non-indigenous people, respectively. In addition, $40 \%$ of indigenous people live in extreme poverty and $31.1 \%$ are not formally educated compared to $14.3 \%$ and $15.4 \%$ of non-indigenous, respectively [10]. Inequality increases even more when indigenous people migrate in search of better opportunities. Migration mostly occurs from small rural towns to large, developed cities, which involves numerous risks for the social determinants of health. Indigenous migrants settle in marginalized areas, suffering discrimination, social undervaluation and labour exploitation; males are usually employed as construction workers or work in the informal economy, while females are mostly hired for domestic work, with no social benefits $[8,11]$.

There is a gap in the knowledge about the social determinants of health in indigenous populations that migrate from rural to urban areas. Nuevo Leon is an example of such internal migration. This north-eastern state is highly industrialized and has become a destination for indigenous migrants [11]. They come from different parts of the country such as San Luis Potosí (Tenek, Nahuas), Querétaro (Otomies), Oaxaca (Mixtecos, Triquis) and Veracruz (Nahuas), among others. Here, there are 59,196 people who speak an indigenous language ( $1.2 \%$ of the state's inhabitants) and its metropolitan area has reached an annual indigenous immigration growth rate of $12 \%$ [12]. However, it is not known to what degree the social determinants of health differ between indigenous migrants and non-indigenous people who are born and raised locally. Regions such as this require evidence for establishing public policies to correct inequalities before irreversible health outcomes occur. The objective of the present study was to compare social determinants of health between indigenous migrants and non-indigenous people from urban Nuevo Leon, Mexico. Additionally, we sought to rank the priorities for addressing the negative social determinants of health.

\section{Materials and Methods}

This was a population-based comparative cross-sectional study. A two-stage nonrandom sampling was carried out from June to August of 2019. The first phase consisted of identification and selection of geographical areas home to indigenous migrants and nonindigenous locals (target populations). Two adjacent neighbourhoods were located (one in front of the other); the indigenous migrant cluster was endorsed by a non-profit ZihuameMochilla organization and the non-indigenous cluster by local government authorities. The second phase consisted of recruiting, from house to house, the person that a given family recognized as the head of the household, i.e., the person who contributed the most to the family's economy. Household heads were consecutively selected after having verified the selection criteria of minimum 18 years and being able to communicate in Spanish. If the head of the family was not available at the time of the visit, a second and third visit were scheduled. The response rate was $98 \%$ for indigenous migrants and $97 \%$ for non-indigenous people. Two eligible indigenous migrants' household heads were excluded as they were under the influence of alcohol/psychotropic substances at the time of the interview. In a pilot study, we identified an average difference of 16 percentage points of six social determinants between indigenous migrants and non-indigenous people. We estimated 117 individuals as the minimum sample size in each group considering previous difference in the calculation with power of $80 \%$ and alpha of 0.05 . We included 235 indigenous migrants and 168 non-indigenous. The protocol was approved by the Committee of Ethics and Health Research (17-FaSPyN-SA-13.TP). The corresponding informed consent was provided by all the participants and the Helsinki declaration was respected.

\subsection{Indigenous Migrant and Non-Indigenous Status}

There were three elements that defined an indigenous individual: (a) the use of an indigenous language, (b) self-ascription (that was, recognizing oneself as such) and (c) belonging to a home where there is a person who speaks an indigenous language. 
Migrant status was defined according to place of birth. The participants were categorized as indigenous migrants and non-indigenous (non-migrant).

\subsection{Social Determinants of Health}

Structural and intermediary determinants of health were distinguished as stated by the World Health Organization Conceptual Framework on the Social Determinants of Health [3]. Structural determinants consisted of education (absent, primary and secondary, or higher), occupation (informal or formal economy work), monthly family income ( $<2$ or $\geq 2$ minimum wages equivalent to 272.7 USD) and social protection (Prospera beneficiary or non-beneficiary). Four categories of intermediary determinants of health were included: (a) housing: ownership, metal-galvanized iron sheets in walls and roofs and overcrowding ( $\geq 3$ persons-per-room; yes or no); (b) behavioural: daily tobacco smoking, excessive consumption of alcohol at least once a week, age $\leq 18$ at first intercourse and contraceptive use at first intercourse (yes or no); (c) health service accessibility: affiliation with a public health care system, health care use in the last 12 months, has been ill $\geq 15$ days without seeking health care, perceives long the traveling time between home and health care facility, perceives long the health care waiting time and work prevents from seeking health care (yes or no); (d) social cohesion: this was measured with the Neighbourhood Social Cohesion Scale Spanish version [13], which is based on the English version that has showed acceptable psychometric properties [14,15]. It consisted of four subscales: interpersonal trust $(10$ items, alpha $=0.75)$, sense of belonging $(4$ items, alpha $=0.55)$, participatory behaviour $(7$ items, alpha $=0.52)$ and shared identity $(2$ items, alpha $=0.75)$. Participants responded using a 5-point Likert scale. All items were written in the positive sense, with higher scores indicating greater social cohesion. Mean scores were transformed into a $0-10$ scale and categorized as low $(<4)$, moderate (4 to 7$)$ and high $(\geq 8)$.

\subsection{Well-Being (Physical Health Status and Psychological Distress)}

History of previous diagnosis of diabetes mellitus, hypertension, heart disease and dyslipidaemia was identified, as was information on any disability (visual, hearing, or motor impairment). Psychological distress was measured with the Kessler K-10. This is a short screening scale with easy application that is used in population-based studies [16,17]. It has shown acceptable psychometric properties in Aboriginal Australians [18] and Mexicans (Spanish version) [19]. It consisted of 10 items related to anxiety and depression symptoms, with responses in a 5-point Likert scale (alpha $=0.83)$. All items were written in the positive sense, with higher scores indicating greater psychological distress. The minimum possible score was 10 and the maximum was 50 . Answers were categorized into low (10-15), moderate (16-21), high (22-29) and very high psychological distress (30-50).

\subsection{Sociodemographic and Other Variables}

Age, sex, marital status, years of education, type of family and head of the family (father or mother) were all considered as sociodemographic variables. Participants were interviewed by trained personnel (a medical doctor, a social worker and a nutritionist). Interviews ranged in duration from 15 to $20 \mathrm{~min}$. At the end of an interview, height (in centimetres) and weight (in kilograms) were measured using a Taylor $\left({ }^{\circledR} \mathrm{USA}\right)$ portable digital scale (Oak Brook, Chicago, IL, USA), calibrated daily and a wall stadiometer. Measurements were taken without shoes and with light clothing, with feet together and heels, back and hips touching the wall. The body mass index was calculated as weight/height ${ }^{2}$ $\left(\mathrm{kg} / \mathrm{m}^{2}\right)$ and classified as follows: underweight or normal weight, $<25 \mathrm{~kg} / \mathrm{m}^{2}$; overweight, $25-29 \mathrm{~kg} / \mathrm{m}^{2} ;$ obesity, $\geq 30 \mathrm{~kg} / \mathrm{m}^{2}$.

\subsection{Statistical Analysis}

Frequencies were obtained for the categorical variables, as were means and standard deviations for the non-categorical variables. Differences between indigenous migrants and non-indigenous were analysed with the chi-square test and univariate odds ratios with 
$95 \%$ of confidence intervals (CI). Priorities were determined by social determinant of health and ranked according to $\mathrm{Z}$-scores: $\mathrm{Zi}=(\mathrm{X} \mathrm{i}-\overline{\mathrm{X}}) / \mathrm{S}$, where $\mathrm{X} \mathrm{i}$ was the observed value of each measure, $\bar{X}$ was the average and $S$ was the standard deviation.

\section{Results}

The mother was the head of the family in $59.2 \%$ of indigenous migrant households and in $55.7 \%$ of non-indigenous homes; $42 \%$ of indigenous migrants were born in southeast Mexico and $88.2 \%$ spoke Nahuatl. Most of them had more than 20 years in the current address. There were no age differences between indigenous migrants and non-indigenous people ( $40.9 \pm 14.2$ vs. $42.4 \pm 14.5$ years, $p>0.05)$, but fewer indigenous migrants were married or had a nuclear family $(45.9 \%$ vs. $58.3 \%$ and $58.3 \%$ vs. $76.2 \%$, respectively; $p<0.05)$. They also had fewer years of education $(7.2 \pm 3.8$ vs. $8.5 \pm 3.4, p<0.05)$.

\subsection{Social Determinants of Health}

All structural determinants were equivalent between indigenous migrants and nonindigenous people, except for one-being a migrant indigenous individual increased 1.6 times the odds of low education (Table 1 ).

Table 1. Structural determinants of health according to indigenous migrant and non-indigenous category.

\begin{tabular}{|c|c|c|c|c|c|}
\hline Factor & $\begin{array}{c}\text { Indigenous } \\
\text { Migrants } \\
(n=235) \\
\text { Number (\%) }\end{array}$ & $\begin{array}{c}\text { Non-Indigenous } \\
(n=168) \\
\text { Number }(\%)\end{array}$ & Odds Ratio & $95 \% \mathrm{CI}$ & $p$ Value \\
\hline None or primary education & $129(55.4)$ & $73(43.5)$ & 1.6 & $1.1,2.4$ & 0.02 \\
\hline Informal economy worker & $150(64.4)$ & $109(64.9)$ & 1.0 & $0.6,1.5$ & 0.92 \\
\hline Family monthly income $<2$ minimum wages ( $\$ 272.7$ USD) & $111(47.2)$ & $67(44.1)$ & 1.5 & $0.9,2.3$ & 0.07 \\
\hline Non-beneficiary of the Prospera program & $188(80.7)$ & $142(84.5)$ & 0.9 & $0.5,1.3$ & 0.32 \\
\hline
\end{tabular}

Most of the intermediary determinants were unfavourable for the indigenous migrant population; being an indigenous individual increased the odds of poor housing, unhealthy behaviour and low social cohesion (Table 2).

\subsection{Well-Being (Physical Health and Psychological Distress)}

History of health conditions was similar between indigenous migrants and nonindigenous people, except for diabetes. Being an indigenous migrant increased the odds of self-reported diabetes by up to 1.7 times. Up to one-third registered high or very high psychological distress and there were no differences by indigenous migrant and non-indigenous category (Table 3).

Table 2. Intermediary determinants of health according to indigenous migrant and non-indigenous category.

\begin{tabular}{|c|c|c|c|c|c|}
\hline Factor & $\begin{array}{c}\text { Indigenous } \\
\text { Migrants } \\
(n=235) \\
\text { Number (\%) }\end{array}$ & $\begin{array}{c}\text { Non- } \\
\text { Indigenous } \\
(n=168) \\
\text { Number }(\%)\end{array}$ & $\begin{array}{l}\text { Odds } \\
\text { Ratio }\end{array}$ & $95 \% \mathrm{CI}$ & $p$ Value \\
\hline \multicolumn{6}{|c|}{ Housing } \\
\hline Not owned & $103(50.5)$ & $51(36.7)$ & 1.8 & $1.1,2.7$ & 0.01 \\
\hline $\begin{array}{c}\text { Roof made of metal-galvanized } \\
\text { iron sheets }\end{array}$ & 89 (37.9) & $16(9.5)$ & 5.7 & $3.2,10.3$ & 0.0001 \\
\hline $\begin{array}{c}\text { Walls made of metal-galvanized } \\
\text { iron sheets }\end{array}$ & $31(13.2)$ & $5(3.0)$ & 5.0 & $1.9,13.0$ & 0.0001 \\
\hline Overcrowding & $41(17.4)$ & $10(6.0)$ & 3.3 & $1.6,6.9$ & 0.001 \\
\hline
\end{tabular}


Table 2. Cont.

\begin{tabular}{|c|c|c|c|c|c|}
\hline Factor & $\begin{array}{c}\text { Indigenous } \\
\text { Migrants } \\
(n=235) \\
\text { Number (\%) }\end{array}$ & $\begin{array}{c}\text { Non- } \\
\text { Indigenous } \\
(n=168) \\
\text { Number }(\%)\end{array}$ & $\begin{array}{l}\text { Odds } \\
\text { Ratio }\end{array}$ & $95 \%$ CI & $p$ Value \\
\hline \multicolumn{6}{|c|}{ Behavioural } \\
\hline Smoking & $105(45.3)$ & $52(31.0)$ & 1.8 & $1.2,2.8$ & 0.004 \\
\hline Drinking & $135(58.2)$ & $81(48.5)$ & 1.5 & $0.9,2.2$ & 0.06 \\
\hline Age $\leq 18$ at first intercourse & 138 (61.9) & $65(41.9)$ & 2.2 & $1.5,3.4$ & 0.001 \\
\hline $\begin{array}{l}\text { No contraceptive use at } \\
\text { first intercourse }\end{array}$ & $184(82.1)$ & $110(68.8)$ & 2.1 & $1.3,3.4$ & 0.002 \\
\hline \multicolumn{6}{|c|}{ Health service accessibility } \\
\hline $\begin{array}{l}\text { Not affiliated with a public } \\
\text { health care system }\end{array}$ & $32(13.7)$ & $28(16.7)$ & 0.8 & $0.5,1.4$ & 0.42 \\
\hline $\begin{array}{l}\text { Has not used health care in the } \\
\text { last } 12 \text { months }\end{array}$ & $141(60.5)$ & $118(70.7)$ & 0.6 & $0.4,0.97$ & 0.04 \\
\hline $\begin{array}{l}\text { Has been ill } \geq 15 \text { days without } \\
\text { seeking health care }\end{array}$ & $25(27.5)$ & $13(26.5)$ & 1.0 & $0.5,2.3$ & 0.90 \\
\hline $\begin{array}{l}\text { Perceives long the traveling } \\
\text { time between home and health } \\
\text { care facility }\end{array}$ & $49(53.3)$ & $32(65.3)$ & 0.6 & $0.3,1.2$ & 0.17 \\
\hline $\begin{array}{l}\text { Perceives long the health care } \\
\text { waiting time }\end{array}$ & $44(47.8)$ & $29(59.2)$ & 0.6 & $0.3,1.3$ & 0.20 \\
\hline $\begin{array}{l}\text { Work prevents from seeking } \\
\text { health care }\end{array}$ & $30(37.0)$ & $24(42.1)$ & 0.8 & $0.4,1.6$ & 0.55 \\
\hline \multicolumn{6}{|c|}{ Social cohesion } \\
\hline Low interpersonal trust & $152(65.2)$ & $83(49.4)$ & 1.9 & $1.3,2.9$ & 0.001 \\
\hline Low sense of belonging & $108(46.6)$ & $48(28.7)$ & 2.2 & $1.4,3.3$ & 0.0001 \\
\hline Low participatory behaviour & $213(91.4)$ & $160(95.2)$ & 0.5 & $0.2,1.2$ & 0.14 \\
\hline Low shared identity & $179(77.2)$ & $112(67.1)$ & 1.7 & $1.1,2.6$ & 0.03 \\
\hline
\end{tabular}

Table 3. Physical health and psychological distress according to indigenous migrant and nonindigenous category.

\begin{tabular}{|c|c|c|c|c|c|}
\hline Indicator & $\begin{array}{c}\text { Indigenous } \\
\text { Migrants } \\
(n=235) \\
\text { Number (\%) }\end{array}$ & $\begin{array}{c}\text { Non- } \\
\text { Indigenous } \\
(n=168) \\
\text { Number }(\%)\end{array}$ & $\begin{array}{l}\text { Odds } \\
\text { Ratio }\end{array}$ & $95 \% \mathrm{CI}$ & $p$ Value \\
\hline \multicolumn{6}{|l|}{ Physical health } \\
\hline Diabetes & $86(36.9)$ & $42(25.1)$ & 1.7 & $1.1,2.7$ & 0.01 \\
\hline Hypertension & $72(30.9)$ & $56(33.5)$ & 0.9 & $0.6,1.4$ & 0.58 \\
\hline Heart disease & $17(7.3)$ & $9(5.4)$ & 1.4 & $0.6,3.2$ & 0.45 \\
\hline Dyslipidaemia & $40(17.2)$ & $30(18.0)$ & 0.9 & $0.6,1.6$ & 0.84 \\
\hline Disability & $23(9.9)$ & $14(8.4)$ & 1.2 & $0.6,2.4$ & 0.61 \\
\hline Overweight or obesity & $183(79.6)$ & $130(78.8)$ & 1.0 & $0.6,1.7$ & 0.85 \\
\hline \multicolumn{6}{|l|}{ Psychological distress } \\
\hline High or very high & $72(31.0)$ & $41(24.6)$ & 1.4 & $0.9,2.2$ & 0.16 \\
\hline
\end{tabular}

\subsection{Priority Ranking}

Housing, behaviours and health service accessibility were top priorities for indigenous migrants, as well as structural determinants for non-indigenous people (Table 4).

Table 4. Priority ranking for addressing social determinants and health needs according to indigenous migrant and non-indigenous category.

\begin{tabular}{ccccc}
\hline Factor & $\begin{array}{c}\text { Indigenous } \\
\text { Migrants' } \\
\mathbf{Z ~ S c o r e ~}^{\mathbf{a}}\end{array}$ & $\begin{array}{c}\text { Priority } \\
\text { Ranking }^{\text {Sank }}\end{array}$ & $\begin{array}{c}\text { Non- } \\
\text { Indigenous Z } \\
\text { Score }\end{array}$ & $\begin{array}{c}\text { Priority } \\
\text { Ranking }\end{array}$ \\
\hline Structural & 0.0 & 4 & 0.0 & 1 \\
Housing & -2.8 & 1 & 2.8 & 4 \\
Behavioural & -2.8 & 1 & 1.4 & 2 \\
\hline
\end{tabular}


Table 4. Cont.

\begin{tabular}{ccccc}
\hline Factor & $\begin{array}{c}\text { Indigenous } \\
\text { Migrants' }^{\text {Z Score }}{ }^{\text {a }}\end{array}$ & $\begin{array}{c}\text { Priority } \\
\text { Ranking }\end{array}$ & $\begin{array}{c}\text { Non- } \\
\text { Indigenous Z } \\
\text { Score }^{\text {a }}\end{array}$ & $\begin{array}{c}\text { Priority } \\
\text { Ranking }\end{array}$ \\
\hline $\begin{array}{c}\text { Health services accessibility } \\
\text { Social cohesion }\end{array}$ & -2.8 & 1 & 2.8 & 4 \\
$\begin{array}{c}\text { Physical health and/or } \\
\text { psychological distress }\end{array}$ & -1.4 & 3 & 2.4 & 2 \\
\hline a A high and negative Z score indicates higher priority.
\end{tabular}

${ }^{\mathrm{a}} \mathrm{A}$ high and negative $\mathrm{Z}$ score indicates higher priority.

\section{Discussion}

This is the first study in Mexico to compare indigenous migrants and non-indigenous urban residents and rank priorities for addressing the negative social determinants of health. Education was the only structural determinant that differed in the indigenous migrant category; indigenous individuals had a $60 \%$ higher chance of receiving low education. Moreover, the frequency of low education was high in both populations, with values (55\% and $44 \%$ ) greater than the state-wide $25 \%$ and the nationwide $34 \%$ [20]. A study from southeast Mexico revealed that $85 \%$ of indigenous people and $75 \%$ of non-indigenous people had primary or no education [21]. For decades, low academic performance and high school dropout have been observed in indigenous communities. Migration from rural areas to cities makes it difficult to satisfy the educational demands of ethnically distinctive populations and intercultural education policies need to be reinforced $[8,9]$. Occupation and income were critical and more than $60 \%$ of our studied groups were in the informal economy and a high percentage of households had a low income, irrespective of indigenous or migrant status. People leave school to obtain a job to support the family economy; this is paradoxical, since lower education is strongly linked to poorly paid occupations. Mexico offers the Basic Education Scholarship Program and the Universal Scholarship Program for high school students who pursue equitable education, as well as for those who live in vulnerable conditions. Marketing strategies are important for allowing communities to take advantage of these resources, since the percentage of beneficiaries from the previous social program, called Prospera, was remarkably low.

Various intermediate social determinants evidenced inequality. Housing was the highest priority addressed among indigenous migrants; an indigenous migrant was 5-6 times more likely to have a house made of poor-quality materials. Noticeably, neighbourhoods were close to each other, showing ancestral gaps had not yet been overcome. Housing remediation is not easy given financial constraints and interventions should consider public-private partnerships. Smoking, sex at young age and no contraceptive protection were also high priorities to be addressed among indigenous migrants. An indigenous migrant was twice as likely to be an active smoker. Prevalence of smoking was higher among indigenous migrants (45\%) than at the state and national levels (25\% and $17.6 \%$, respectively) [22]. The south-eastern Mexican study showed that $15.9 \%$ and $9.4 \%$ of indigenous and non-indigenous people were smokers, respectively [21]. Nuevo Leon is one of the 11 states with smoke-free laws. Nationwide policies include restrictions on tobacco advertising, high purchase taxes and health warnings on packages. There is even a phone line to aid in stopping smoking [22]. Without a doubt, much remains to be achieved. Another behavioural social determinant was alcohol consumption. The difference in the frequency of drinkers between populations was marginal, though there was a tendency among indigenous migrants to be greater drinkers. Other studies have found no disparity between indigenous and non-indigenous groups [5,21]. Accessibility to health services was equivalent in all but one factor. A lack of utilization was high in both populations, but it was worse among non-indigenous people. Medical facilities being distant and not being able to miss work may have influenced these factors. The higher prevalence of diabetes among indigenous migrants may have led to more visits to the doctor. As such, the non-use rate was lower among this population; however, more research is needed to identify the source of these differences. Affiliation with a public health care system was remarkably 
high, irrespective of indigenous or migrant status; more than 8 of 10 were affiliated with a public health care system. The 2012 Health and Nutrition Survey showed that $73 \%$ of indigenous people and $77 \%$ of non-indigenous people were affiliated with a public health care system [23]. Mexico has implemented different government initiatives for highly marginalized groups to reduce vulnerability. The Instituto de Salud para el Bienestar was founded in 2020 to provide free health services to people who do not have social security medical services (IMSS or ISSSTE).

Social cohesion is the bridge between structural and intermediary determinants. Three of four aspects of social cohesion differed between indigenous migrants and nonindigenous people. Markwick et al. [5] identified that 27.3\% of Aboriginal Australians are untrusting compared to $20.9 \%$ of the non-Aboriginal population. In our study, frequencies were much higher: $65.2 \%$ of indigenous migrants and $49.4 \%$ of non-indigenous people had low interpersonal trust. Low trust may be a consequence of being a victim of discrimination and exploitation. Socially integrated communities share benefits. Social cohesion is important for the productive functioning of society and, therefore, health [24]. Regarding physical well-being, one-third of indigenous migrants and non-indigenous people had similar histories of hypertension, but self-reported diabetes was higher among indigenous migrants (37\%), despite age and obesity similarities. The prevalence of diabetes among indigenous populations in Mexico ranges from 0 (Huicholes) to 26.2\% (Mixtecos) [25]. The prevalence of diabetes among indigenous populations in Australia ranges from 3.5 to $33.1 \%$ [26]. In many developed countries, indigenous populations have higher prevalence of diabetes, but the pattern is inconsistent and differences may be attributed to adopted obesogenic lifestyles and genetic predispositions [26,27]. Jiménez et al. [21] identified a significant effect of the interaction between indigenous origin and family history on the risk of diabetes (odds ratio $=3.1,95 \%$ CI 1.3-7.5). On the other hand, there is an increasing body of literature demonstrating that stressors that cause deterioration on the biological system may progress to negative long-term health outcomes. We identified one-third of indigenous migrants and non-indigenous people as having similar high or very high psychological distress. In Australia, being an indigenous person doubled this risk of psychological distress [5]. Interventions such as mindfulness-based stress reduction may be beneficial [28].

\section{Limitations of the Study}

The study only included urban residents. Structural issues, health service accessibility and psychological distress, among other factors, may differ between urban and rural environments. Additionally, caution is needed when generalizing these results to rural residents. Self-reported data were subject to the obtaining of socially acceptable responses, e.g., behavioural questions; to obtain inaccurate responses to sensitive topics, e.g., family income question; or to obtain inaccurate responses due to memory recall or subjective perception, e.g., traveling and waiting times questions. Consequently, underreporting may be present. However, if bias did occur, it did so in both populations. Disparities cannot be attributed solely to ethnicity or migration; there are historical, political and sociocultural backgrounds that should also be considered. It is necessary to continue studying disparities between migrant populations.

\section{Conclusions}

Social determinants of health and their priority rankings differed between indigenous migrants and non-indigenous people from urban north-eastern Mexico. For indigenous migrants, disparities were evident in one structural social determinant (low education) and three intermediate (poor housing, non-healthy behaviours and poor access to health services) determinants. These findings show that the right to the social determinants of health has not yet been guaranteed for indigenous communities. Housing and behavioural factors are top priorities to be addressed among indigenous migrants. Public policies are required for reducing inequality gaps. The 2019-2024 Sectorial Health Program includes 
interculturality policies for fulfilling indigenous rights and guaranteeing comprehensive care [29]; these are major challenges for all levels of government. The question remains as to whether the measures will be able to finally close the historical gaps that have affected and continue to affect, indigenous peoples.

Author Contributions: G.M.N.-R., B.M.E.-E., M.N.Á.-O., A.E.C.-S., A.Z.-M. and K.J.H.-R. designed the study. G.M.N.-R., A.M.S.-M. and B.M.E.-E. performed the analyses and drafted the manuscript. G.M.N.-R., A.M.S.-M., M.N.Á.-O., A.E.C.-S., A.Z.-M. and K.J.H.-R. revised the paper. All authors have read and agreed to the published version of the manuscript.

Funding: This study was funded in part by the Support Program for Scientific and Technological Research (PAICYT) of the Autonomous University of Nuevo León (Funding No. SA-773-19).

Institutional Review Board Statement: The study was approved by the Ethics and Research Committee of the School of Public Health and Nutrition of the Autonomous University of Nuevo León with the registration number 17-FaSPyN-SA-13.TP. All ethical principles for medical research involving human subjects of the Helsinki declaration were respected.

Informed Consent Statement: Informed consent was obtained from all subjects who participated in the study, the form of which is attached.

Acknowledgments: We thank María del Carmen Farias Campero, president of the Zihuame-Mochilla A.C. (http:/ / www.zihuame.org.mx/ (accessed on 8 July 2021), for their support and collaboration for this study. We also thank nutritionist Mónica Alejandra López Novelo and social worker Brenda Berenice Tovar Jasso for their collaboration in the data collection.

Conflicts of Interest: The authors declare no conflict of interest.

\section{References}

1. World Health Organization. Health in the Post-2015 Development Agenda: Need for a Social Determinants of Health Approach. Joint Statement of the UN Platform on Social Determinants of Health. Available online: https:/ /www.who.int/publications/m/ item/health-in-the-post-2015-development-agenda-need-for-a-social-determinants-of-health-approach (accessed on 7 July 2021).

2. World Health Organization. Closing the Health Equity Gap. Policy Options and Opportunities for Action. Available online: https://apps.who.int/iris/bitstream/handle/10665/78335/9789241505178_eng.pdf;jsessionid=CE00852FCC608B29F91E1 C0A21B027B1?sequence $=1$ (accessed on 8 July 2021).

3. A Conceptual Framework for Action on the Social Determinants of Health 2010; World Health Organization (WHO): Geneva, Switzerland, 2010; p. 76.

4. Mitrou, F; Cooke, M.; Lawrence, D.; Povah, D.; Mobilia, E.; Guimond, E.; Zubrick, S.R. Gaps in Indigenous disadvantage not closing: A census cohort study of social determinants of health in Australia, Canada, and New Zealand from 1981-2006. BMC Public Health 2014, 14, 201. [CrossRef] [PubMed]

5. Markwick, A.; Ansari, Z.; Sullivan, M.; Parsons, L.; McNeil, J. Inequalities in the social determinants of health of Aboriginal and Torres Strait Islander People: A cross-sectional population-based study in the Australian state of Victoria. Int. J. Equity Health 2014, 13, 91. [CrossRef] [PubMed]

6. Gracey, M.; King, M. Indigenous health part 1: Determinants and disease patterns. Lancet 2009, 374, 65-75. [CrossRef]

7. Gamlin, J.; Osrin, D. Preventable infant deaths, lone births and lack of registration in Mexican indigenous communities: Health care services and the afterlife of colonialism. Ethn. Health 2020, 25, 925-939. [CrossRef] [PubMed]

8. Consejo Nacional de Población. Infografía Población Indígena; Consejo Nacional de Población: Ciudad de México, Mexico, 2015.

9. Comisión Nacional para el Desarrollo de los Pueblos Indígenas. Programa Especial de los Pueblos Indígenas 2014-2018. Available online: https:/ /www.gob.mx/cms/uploads/attachment/file/32305/cdi-programa-especial-pueblos-indigenas-2014-2018.pdf (accessed on 11 April 2021).

10. Consejo Nacional de Evaluación de la Política de Desarrollo Social. Medición de Pobreza 2018. Available online: https: //www.coneval.org.mx/Evaluacion/PublishingImages/Pobreza_2018/POBLACION_PERTENENCIA_ETINICA.jpg (accessed on 5 July 2021).

11. Granados Alcantar, J.A.; Quezada Ramírez, M.F. Tendencias de la migración interna de la población indígena en México, 1990-2015. Estudios Demográficos Urbanos 2018, 33, 327. [CrossRef]

12. García Tello, D.P. La espacialidad de los indígenas en el área metropolitana de Monterrey. Relaciones 2013, 134, 57-92.

13. Betanzo, A.; Alcalá, E.; Aldana, L. Bases para la Construcción de un Îndice de Cohesión Social Vecinal; Fundación Hogares y México Evalúa: Michoacán, Mexico, 2015.

14. Ross, A.; Searle, M. Conceptualization and validation of the Neighbourhood Cohesion Index using exploratory structural equation modelling. Community Dev. J. 2020, 56, 408-413. [CrossRef] 
15. Dickes, P.; Valentova, M.; Borsenberger, M. Construct Validation and Application of a Common Measure of Social Cohesion in 33 European Countries. Soc. Indic. Res. 2010, 98, 451-473. [CrossRef]

16. Kessler, R.C.; Andrews, G.; Colpe, L.J.; Hiripi, E.; Mroczek, D.K.; Normand, S.L.T.; Walters, E.E.; Zaslavsky, A.M. Short screening scales to monitor population prevalences and trends in non-specific psychological distress. Psychol. Med. 2002, 32, 959-976. [CrossRef] [PubMed]

17. Furukawa, T.A.; Kessler, R.C.; Slade, T.; Andrews, G. The performance of the K6 and K10 screening scales for psychological distress in the Australian National Survey of Mental Health and Well-Being. Psychol. Med. 2003, 33, 357-362. [CrossRef] [PubMed]

18. McNamara, B.J.; Banks, E.; Gubhaju, L.; Williamson, A.; Joshy, G.; Raphael, B.; Eades, S.J. Measuring psychological distress in older Aboriginal and Torres Strait Islanders Australians: A comparison of the K-10 and K-5. Aust. N. Z. J. Public Health 2014, 38, 567-573. [CrossRef] [PubMed]

19. Vargas Terrez, B.E.; Villamil Salcedo, V.; Rodríguez Estrada, C.; Pérez Romero, J.; Cortés Sotres, J. Validity of the kessler 10 (k-10) scale in detecting depression and anxiety disorders in the primary care services. Psychom. Prop. Salud Ment. 2011, 34, $323-331$.

20. Instituto Nacional de Estadística y Geografía. Población de 3 Años y Más con Algún Grado Escolar por Entidad Federativa. 2020. Available online: https:/ / www.inegi.org.mx/app/tabulados/interactivos/?pxq=Educacion_Educacion_04_10b76194-2880-4907-abed$51 \mathrm{fd} 37557 \mathrm{~d} 17$ (accessed on 15 July 2021).

21. Jimenez-Corona, A.; Nelson, R.G.; Jimenez-Corona, M.E.; Franks, P.W.; Aguilar-Salinas, C.A.; Graue-Hernandez, E.O.; HernandezJimenez, S.; Hernandez-Avila, M. Disparities in prediabetes and type 2 diabetes prevalence between indigenous and nonindigenous populations from South-eastern Mexico: The Comitan Study. J. Clin. Transl. Endocrinol. 2019, 16, 100191. [CrossRef] [PubMed]

22. Instituto Nacional de Psiquiatría Ramón de la Fuente Muñiz; Instituto Nacional de Salud Pública; Comisión Nacional Contra las Adicciones. Encuesta Nacional de Consumo de Drogas, Alcohol y Tabaco 2016-2017: Reporte de Tabaco; INPRFM: Ciudad de México, Mexico, 2017.

23. Leyva-Flores, R.; Infante-Xibille, C.; Gutiérrez, J.P.; Quintino-Pérez, F. Persisting health and health access inequalities in Mexican indigenous population, 2006-2012. Salud Publica Mex. 2013, 55, S123-S128. [CrossRef] [PubMed]

24. Consejo Nacional de Evaluación de la Política de Desarrollo Social. Cohesión Social: Balance Conceptual y Propuesta TeóricoMetodológica. Available online: https://www.coneval.org.mx/informespublicaciones/informespublicaciones/documents / cohesion_social_balance_conceptual.pdf (accessed on 18 January 2021).

25. Buichia-Sombra, F.G.; Dórame-López, N.A.; Miranda-Félix, P.E.; Castro-Juarez, A.A.; Esparza-Romero, J. Prevalence and factors associated with type 2 diabetes mellitus in the indigenous population of Mexico: Systematic review. Rev. Med. Inst. Mex. Seguro Soc. 2020, 58, 317-327. [CrossRef] [PubMed]

26. Minges, K.E.; Zimmet, P.; Magliano, D.J.; Dunstan, D.W.; Brown, A.; Shaw, J.E. Diabetes prevalence and determinants in Indigenous Australian populations: A systematic review. Diabetes Res. Clin. Pract. 2011, 93, 139-149. [CrossRef] [PubMed]

27. Schulz, L.O.; Chaudhari, L.S. High-Risk Populations: The Pimas of Arizona and Mexico. Curr. Obes. Rep. 2015, 4, 92-98. [CrossRef] [PubMed]

28. Crowe, M.; Jordan, J.; Burrell, B.; Jones, V.; Gillon, D.; Harris, S. Mindfulness-based stress reduction for long-term physical conditions: A systematic review. Aust. N. Z. J. Psychiatry 2016, 50, 21-32. [CrossRef] [PubMed]

29. Secretaría de Salud. Programa Sectorial de Salud 2019-2014. Available online: http://saludsinaloa.gob.mx/wp-content/uploads/ 2019/transparencia/PROGRAM_SECTORIAL_DE_SALUD_2019_2024.pdf (accessed on 4 July 2021). 